\title{
Digitizing Refugee Camps: Promotion of Mobile Communication for Charter Governance
}

\author{
Gbemisola Adegboye \\ New York Institute of Techology-Vancouver \\ Lawrence W.C. Lai \\ Ronald Coase Centre for Property Rights Research \\ University of Hong Kong \\ Frank T. Lorne \\ New York Institute of Technology-Vancouver
}

\section{Preamble:}

The question....is not whether billions of people will soon gather together in cities, but where and under what conditions. Under conditions of policy-as-usual, people will flock to slums that surround cities whose governments either do not want additional residents or are incapable of accommodating them. Many people will become second-class citizens in informal settlements that, by definition, offer none of the protections that formal rules can provide. Even for migrants who manage to gain access to formal systems of rules in the developing world, the protections and opportunities in the cities that will accept them will often be well below those offered by the rules in the cities where they would rather live (Fuller and Romer, 2012: p.3).

Many refugees are no strangers as global citizens, highly-educated, entrepreneurial, and happen to be trapped in circumstances that waste their universal values and potential. This situation is not sustainable.

\section{INTRODUCTION}

Refugee camps, ${ }^{\text {i }}$ like the Za'atari Camp in Jordan for Syrian refugees, were formally established by the United Nations (UN) as a temporary solution to provide food and shelter to the many people displaced after the Second World War with the expectation that in time, refugees would return home or move to new homes in another country. But many refugees have lived in camps for decades. As long-term conflicts persist, host countries are unwilling to let refugees become part of their citizenry or residential population. The irony is that even highly-skilled and well-educated refugees typically cannot be employed, travel outside the camp, cultivate land, or pursue formal education. In short, very capable and 
skilled people find themselves with limited agency over their lives and futures. Nonetheless, many refugees, both inside and outside camps, have started their own businesses, even when their host countries' laws make it virtually impossible to turn a profit, simply because they are eager to use and develop their skills.

The practical and ethical issues facing refugees, ${ }^{i i}$ as mentioned above, are not only numerous, but varied, and many crises ${ }^{\mathrm{iii}}$ are beyond the scope of this work, which focuses on some new advances in technology and management principles that suggest new directions for the world community to consider. The fundamental value for this goes beyond a paternalistic preferential option for the poor as an abstract concept but optimism in the dignity of the refugees as citizens of the world as human capital with names and faces.

It is suggested that developing a strong local economy in the camps that can digitally integrate with resources within the camp, and the rest of the world will go a long way towards driving prosperity and integrating the people living in the camps with the global economy. Section I will discuss the nature of the problem, along with the magnitude, size, and refugee camp distributions across countries. Section II will point out the neglected attributes of refugees by providing historical examples. Section III will

discuss the political economy of the refugee crisis. Section IV will provide some latest concepts that, if combined with connectivity necessary for experimentation, may open new areas of technology adoption and a new governance structure that may provide leapfrogging opportunities for refugee camps. The last section is the conclusion.

\section{SOLUTIONS: THE NEED FOR A NEW DIRECTION}

Host governments grant temporary visas to refugees who are under UNHCR protection and these visas must be renewed regularly. The goal of the UNHCR is to find one of the three "durable solutions" for refugees: integration ${ }^{\text {iv }}$, repatriation ${ }^{\mathrm{v}}$, or resettlement ${ }^{\mathrm{vi}}$.

All three solutions are geographically focused in that they identify particular applicants for particular localities. This may be a matter of conventional practice, but intrinsically, refugees are simply migrants who want new lives due to diminished circumstances (largely political) in their home countries. Changed circumstances may or may not alter a person's preferences and abilities and the new location where s/he is placed may or may not be suitable for his/her inert skills.

Economists largely believe that all people are endowed with preferences and abilities (including learning abilities) and such endowments can be improved and modified through learning and experiences. The welfare of the world will be improved whenever resources are moved from lower valuation to higher valuation uses; that has always been the economic criteria for improving the welfare of the world.

Yet, the current world of ever-changing technologies and competitiveness moving at such a rapid rate has left many individuals unprepared to compete according to these criteria. A multi-cultural ecosystem of the world will persist and the ideal of a perfect integration of knowledge, habits, and cultures is both a moving target and utopian ideal. It is not at all clear that local integration is a long run solution.

Repatriation, likewise, can be contradictory in terms of the context of refugees' incentives to migrate. Why would someone leaving his/her own country for political reasons ever want to be repatriated? Consider Cuban immigrants in North America which, from a geographical perspective, seems like a convenient match since Cuba is close to the southern tip of Florida, USA. Yet, the migration of Cubans via Key West (Florida's southernmost point) to the continental USA was not a prevalent phenomenon. A very unique Key West culture emerged from years of local residents' enjoyment of seas and weather might had been a main reason. Whenever a particular locality had been preoccupied with its own unique culture, it is usually difficult for newly arrived immigrants to be accepted. Yet, before the divergent political ideology of the two countries evolved, significant efforts had been made to facilitate win-win trade opportunities between them, the most highly-remembered of which was the seven-mile railroad connecting the series of dry land of Key West to the southern tip of the Florida peninsula. ${ }^{\text {vii }}$ Instead, prominent Cuban immigrants in North America have scattered over different areas, with some noted 
mostly for their possible influence over their homeland. Wikipedia alleged some subversive motivations about "Cuban Exiles". viii

Resettlement is most likely what refugees want most, but where, how, and what are the conditions of this process? The world community has focused on asking this question for many years. From the perspective of pure protectionist economic motivation, every country wants to attract the smartest, strongest, prettiest, and wealthiest to its shores. Developing a resettlement policy on these grounds, however, would be non-humanistic and unfair to many. Casting aside selection criteria based on economic merits, each country may have to establish its own ad hoc resettlement policy that does not have strong philosophical backing except in the name of humanitarian considerations.

This paper supports humanitarian concerns for strangers, but submits that there are attributes of refugees, such as their willingness to accept the risk of change, rather than passively adapting to the status $q u o$; and that they are migrants rather than purely handicapped fugitives craving for basic minimum needs. It is a change in policy direction that this paper advocates.

\section{EXAMPLES REVEALING THE CONTRIBUTION OF REFUGEES' HUMAN CAPITAL}

It is a fact that First World nations, such as the USA and Canada, were established by descendants of immigrants who were essentially refugees from host countries with religious persecution, famines, wars and instability. The realistic problems that these refugees needed to confront were uses for lands that were already owned or occupied by others. Even today, refugees leave their countries and means of livelihood to seek refuge in host countries and some end up with good jobs or professions and have contributed positively to the economy of their host countries, if allowed to do so.

Centuries ago in Venice (and Hong Kong later), before the frontier lands of North America were developed, refugees made positive economic impacts on building communities after starting with almost nothing. The prosperity created in the two historical cities did not stem from the decisions of any single person on the level of Alexander the Great or Genghis Khan; indeed, it was the micro dynamics of the many refugees (migrants) who fled their native lands for political reasons. In Venice and Hong Kong, they found parts of them uninhabitable and set about transforming them.

\section{The Importance of Previously Unoccupied Land: Venice}

The history of how Venice was established has been aptly recorded and studied in the literature. (Lai et al 2014a, Lai et al 2019) People living on the Italian Peninsula who wanted to escape Lombard domination fled to the mud beds that comprised the virgin terrain of Venice and needed to be reinforced by wooden piles. That was how this famous water city began. This historical creation, unlike the Great Wall of China and pyramids in Egypt, did not result from the designs and actions of a government. Indeed, government in the form of the Doge (chief) who was appointed by the migrants who gathered in Venice. This example was recently discussed in the context of land reclamation as an experimental public choice. The evolvement of internal politics is easier if there was no prior political structure acting as a constraint. This happened to St. Petersburg in the $18^{\text {th }}$ century and Singapore from 1960 (Lai et al 2014a, 2019).

\section{Refugees Will Prosper if Allowed to Do What They Do the Best}

The Jewish refugees' experiences in the Venice Ghetto from about 1516 is an example of how refugees can contribute to prosperity in spite of discrimination (Roth, 1934; Clapp, 1986). At its peak, the Venice Ghetto had about 5,000 Jews who were forced to live in densities as high as eight people to a room without windows on an island surrounded by canals located outside the city. They could only enter the city during the day and had to return to the ghetto by evening before its gates were shut. They also had to wear badges on their clothing to indicate that they were refugees. Moreover, they were only allowed to be shoemakers, tailors, hawkers, shipbuilders, and moneylenders and were heavily-taxed by the government. Still, they prospered so much to the extent that the moneylenders among them lent money to the rich and poor and even the State. In fact, their displays of wealth aroused the enmity or 
suspicions of many Venetians, but they were so important to Venice's economy that several attempts to expel them were always aborted because it was apparent that the absence of their trading skills would prove detrimental to Venetian commerce. Jewish financial skills and links to Middle Eastern markets helped slow the decline of Venice's maritime superiority.

Despite the ill feeling the Venetians had towards the Jews and the apparent segregation the Jews faced, the latter set up social institutions and maintained cherished traditions in the ghetto. They also built synagogues and schools, with each having its own administrator and rabbi, and held regular religious services. Due to a shared language and commercial integration, there were interactions between Venetians and Jews on almost every social level.

\section{Colonial Hong Kong Refugee Squatters}

In colonial Hong Kong, those living in squatter settlements (which were very similar to refugee camps in many ways) also generated economic value. A study of land and marine squatters in colonial Hong Kong by Lai, Chua, \& Lorne (2014b) revealed that when property rights were allocated to certain types of squatters, it often brought about innovation. If a squatter remained on Crown Land for a long time and was not driven out, but rather treated as a guest and promised better accommodations in the future, $\mathrm{s} /$ he gained a license to remain there. If the government did not promise future transformation or relocation but conferred to the squatter an exclusive license to stay upon the payment of a small fee, the squatter, after paying the fee, gained recognitions over the plot on which s/he squatted.

There were efficient and inefficient forms of squatting. The aforementioned study suggested that marine squatters brought about innovations and contributed significantly to the development of Hong Kong's seafood industry. Specialised squatter hut builders emerged from the ranks of land squatters, although some huts were dangerous and uninhabitable.

\section{Political Impacts Need not Destroy the Spirit of Refugees}

Interestingly, there was another counterpart in Hong Kong to the Venice Ghetto in the form of a government-neutral enclave that evolved from the historical location of a "walled city". The Kowloon Walled City was originally an Imperial Chinese fort with stone walls built in Kowloon across the young British Crown colony of Hong Kong. It became part of a specifically excluded enclave to a large land addendum to the colony through a 100-year lease that lasted from 1898 to 1997 . Due to disputes over its sovereignty, the colonial authorities did not enforce those laws regarding titles and building and planning controls, but clearly delineated its boundaries according to the alignments of its walls, which were destroyed by the Japanese conquerors of Hong Kong during the Second World War. The place became known as the "Kowloon Walled City" from the 1960s until its demolition to signify its outermost limits, which China recognised de jure diplomatically. An uncontrolled number of refugees flooded into this spatially well-defined, but mostly unrestrained, wall-less Chinese territory without Communism and the place flourished as a free trade zone. No violence characterised by anarchy or epidemic, as one may predict for an unregulated town, broke out. Land occupiers collaborated with developers to transform a low-rise cottage zone into high-rise (10-14 storey) concrete buildings with communal lifts and flush water supply. The colonial government only placed a cap on building height to protect civil aviation at nearby Kai Tak airport.

Refugees have proven to be incredibly dynamic and creative when given the opportunity - creating businesses and jobs, providing local goods and services, boosting exports, and increasing the overall income of their host countries. In Jordan's Za'atari camp, they have developed an improvised city of 83,000 people supplied with electricity, markets, boulevards, and education for their children.

\section{THE POLITICAL ECONOMY OF THE REFUGEE CRISIS}

Several international bodies are pivotal in the current refugee crisis. They are the UNHCR and many NGOs. 


\section{UNHCR}

The Office of the United Nations High Commissioner for Refugees (UNHCR) was established in December 1950. The UNHCR's headquarters are in Geneva, Switzerland. In 2008, it boasted 6,351 employees in 117 countries. Its main mission is to help and protect refugees; safeguard their rights; and assist in their voluntary repatriation, local integration, or resettlement in a third country. The UNHCR is not only a government agency, but also an organization with other stakeholders, some of which are nongovernmental organizations (NGOs).

\section{NGOS $^{\text {ix }}$}

The NGOs and the UN were founded in 1945. NGOs are usually non-profit, active in a number of areas such as humanitarian, educational, healthcare, public policy, social, human rights, environmental, and other areas and aim to effect changes according to their objectives in these areas. To help protect social or environmental policies, they can be organized on the community, national, or international level. Basically, an NGO is funded by donations and most are staffed largely by volunteers. They actively assume different forms to participate in various activities and serve specific political or social purposes, especially in the fields of humanitarian aid and poverty alleviation.

In general, the two main humanitarian concerns of these bodies for refugees are protection and assistance. Protection refers to ensuring that their rights are fully-respected and international human rights and refugee laws are followed. Assistance refers to helping those who are affected by disaster or other crises.

Although historically, the UNHCR and NGOs have both been involved in protecting refugees, NGOs are not very satisfied with some of the UNHCR's practices because they believe that its policies are too submissive to the wishes of governments instead of protecting refugees. During the early 1990s, the two drew up a highly ambitious plan for a "partnership in action" (PARinAC) which included recommendations for the coordination of protection activities and only limited progress was made (Schenkenberg van Mierop, 2004).

In the mid-1990s, the UNHCR was criticized for sacrificing its protection mission and focusing on providing assistance only. Throughout the late 1990s, it invited NGOs via the "Reach Out Process on International Protection" in its work. But planned meetings with them in New York, Bangkok, and Nairobi, unfortunately, never materialized (Schenkenberg van Mierop, 2004).

The challenge facing the UNHCR is that it is sometimes caught between the conflicting desires of stakeholders. The conversation with the NGOs had not been entirely transparent and neither were NGOs sometimes being sufficiently focused on their missions. To provide more in-depth assistance to and protection for refugees, both need to cooperate, effectively share information, coordinate, build mutual trust, and expand their common ground to do so.

The efforts of the UNHCR and NGOs are not enough to place the camp's refugees on the road to economic or financial independence and enable them to develop a self-governing infrastructure of economic, social, and political platforms by themselves, which must go beyond meal vouchers and other forms of assistance they presently receive. Maureen Sigliano, the Vice President of Global Loyalty Development for Western Union, spent two years travelling to refugee camps in Kenya, Jordan, Greece, and Uganda to discuss with the inhabitants their needs and see how she could build a refugee assistance program through Western Union philanthropic initiatives. However, she quickly realized that what was needed was an entire overhaul of the system and a transition to a model that supports economic development and independence within the camps. "They don't want charity; they want dignity and they want opportunity" (Sigliano, cited in Anzilotti, 2017). The UNHCR and NGOs must strive to ensure refugees are treated humanely with equal rights as the rest of the world.

The forming of a self-governed refugee city would undoubtedly have to rely on a governance structure that can credibly handle policies and enforce them. Ideally, it should be run as a form of democracy. However, democracy is often not the most efficient form of governance if leadership is lacking. On the other hand, too strong of a particular type of leadership usually results in autocracy. New technologies, in this respect, could provide more effective methods of communication and, thus, produce 
more effective ways to identify capable leaders and their methods of governance. This should, in turn, lead to greater civic participation in the camps.

Several development directions can illustrate how new technologies could provide incentives and communication tools for the relevant agencies to take the intermediate steps needed to form selfgoverning refugee cities.

\section{INCENTIVIZING SELF-GOVERNANCE}

It is paradoxical that there is still so much undeveloped land around the world and yet 64 million people cannot find a place to live. Beautiful islands sit within a country (e.g. Greece, the Philippines, Indonesia, etc.) and have no other function except for people to admire and sometimes to be converted into private islands.

The idea of encouraging new settlers to occupy undeveloped land is not new. It had been tried with great success during the early frontier days of North America. One could argue that the internet's relationship to a country today is like the railroads' relationship to yesterday's frontier. Both provided vital lines of communication for their economies. It matters little where an individual lives, when much of his economic activity can be carried out via the internet. Land in this context is not for its soil to grow food, but as a shelter where individuals can live their lives while conducting business (within and across small groups) online, which many in developed societies are doing already.

Immigrants' incentives are guided by perceptions, necessities, and an urge to be free from their existing status quos. People can develop higher aspirations on things in their minds without migrating. However, aspiring is often not sufficient. Physically moving to another location opens up opportunities as well as uncertainties. Current refugee incentives are heavily-shaped and guided by perceptions given by the UN and more developed countries of the world. There has yet to be a sufficient introduction of technology to refugees' mindsets to provide more balanced aspirations and, hence, giving them a more equal footing in an entrepreneurial world of competition.

Technology has been introduced to refugees in an ad hoc manner, some examples can be found in Shiller (2014), Xu and Maitland (2015), Xu, Maitland, Tomaszewski (2015). The UN World Food Program (WFP) launched a robust pilot program in Jordan in May 2017, prior to which Syrian refugees stationed at the Azraq Refugee Camp received vouchers to shop at local grocery stores. However, after the program's introduction, the WFP integrated blockchain into its biometric authentication technology so that the refugees could cash in their vouchers at supermarkets by staring into retina scanners (Juskalian, 2018). These transactions are recorded on a private Ethereum-based blockchain called Building Blocks, which eliminates the need for the WFP to pay banks to facilitate transactions. Building Blocks can save the WFP each month in bank fees in Jordan alone. In addition to helping the WFP save on bank fees and ensuring that assistance goes directly to the refugees, a blockchain-based system can help them build a more permanent identity. Their transaction records on the blockchain are indelible and may serve as identification in their new country (Hempel, 2018). It is unlikely that particular crytocurrency created for a refugee camp will be disruptive in the sense of being widely used as a world currency (Lorne, et. al., 2018). As a peer to peer method of conducting transactions avoiding bank fees, however, it could be a suitable beachhead for the launching of a technology. For innovation dealing with governance, the choice of a beachhead could be the key too. History has shown that something exceedingly complicated could happen in one day (Anderson, 2018).

\section{Charter Cities}

Related to, but not exclusively dependent on, land grants and various new communication technologies, charter cities, as proposed by recent Economic Nobel Prize winner, Paul Romer, is a new direction of management techniques that can be considered by refugee camp administrators. Romer argued that a developing country (indeed, any country) can pass a law that sets aside a tract of land for a new charter city (Romer, 2010). The significance of a charter city is that it can be administered by a developed "third-party guarantor government" (Fuller and Romer, 2012). 
A charter city is a new type of special reform zone. It extends the concept of a special economic zone by increasing its size to the scale of a city and expanding the scope of its reforms. During this century, which has been characterised by rapid urbanization, charter cities can offer families in the developing world an option that far too many currently lack: a choice of living in several well-run cities, each of which competes to attract them as residents. This combination of choice and competition is the best strategy for improving the worldwide quality of life. Romer and Fuller believe that charter cities will empower those who move there to earn wages that are three to seven times higher than the wages without charter cities. They estimate that this could increase worldwide income by $50 \%$ to $150 \%$.

The charter cities proposal suggests that developing countries can partner with credible allies by using reform zones to implement rules that are known to work well. By starting on new sites, the formal rules in charter cities would be seen as legitimate by migrants who move there and the norms they encourage can differ markedly from the ones that prevail elsewhere in the country.

\section{Essential Characteristics of Charter Cities}

A charter city's governance structure can vary significantly depending on where it is established, but all charter cities share four common traits:

1. They started out as undeveloped plots of land set aside by their host nations that are large enough to eventually host entire cities of about a million people each.

2. A charter that pre-specifies the broad rules that would apply there often provides a better alternative for both investors and migrants than the institutions in neighboring developing nations. Such rules and institutions would make the city more stable for foreign investment than politically risky developing countries, while migrants would prefer to move to the city to avoid endangering their lives and ultimately eyeing a move to the developed countries in Europe or North America.

3. A commitment to choice backed by both voluntary entry and exit for all residents, employers, and investors. The rules would only apply to those who choose to live in the city and they are free to opt out and move elsewhere.

4. A commitment to the equal treatment of all residents under the law such that there is no favoritism or discrimination.

There are three distinct roles for participating nations: host, source, and partner. The host country provides the land. The source country supplies the people who move to the new city. The partner country helps to ensure that the charter would be respected and enforced indefinitely. Because these roles can be played by a single nation or by several countries working together as partners, there are many potential charter city arrangements. A single country can even assume all three roles, as China did when establishing a special economic zone from which the new city of Shenzhen emerged and attracted migrants from other parts of China. There, the central government acted as a "partner" to the local authorities.

Charter cities would ideally partner with developed nations to help establish effective government services and institutions that would not affect partner nations' aid budgets too much, as some of their services, such as the training of its police, could be paid by the charter city.

Another pertinent point to note under Romer's vision of charter cities is that the city government would own the land on which it is sited, and it would be able to lease out portions of it to private parties to generate revenue.

\section{Extent of Trial and Failure}

Castle-Miller $(2012,2014)$ discussed the trials and failures of charter city implementation in the past. In 2009, Madagascar under President Marc Ravalomanana took a decision to implement a charter city in the nation, but the project was aborted after a coup removed him from office. This shows that political stability in the host country is important for the success of a charter city.

In 2012, the Honduran Government tried to establish a special development region that was partially based on the idea of a charter city. The goal was to give the country and any Honduran who chose to opt 
in a chance to try a new model of development. The Honduran Congress defined a new legal entity called la Región Especial de Desarrollo (RED), which the government aimed to use to establish a reform zone to which families could move safely and legally. The RED government was to be largely autonomous from the central government. Its leadership would have the power to partner with credible foreign governments, such as Canada and Mauritius. The conjecture was to enable in critical areas like policing, the courts, customs, and anti-corruption a new set of rules making the new city a more attractive place for prospective residents and investors and possibly a city that could eventually become a model for the Americas. The concept looked promising, especially with Romer serving as one of the members in the Transparency Commission that was set up to guide its development. However, his involvement with the project did not continue, perhaps due to what he viewed as a lack of transparency on the part of the central government. Honduras is a nation fraught with corruption, favoritism, and institutional and political barriers, none of which allows for the success of a charter city. Castle-Miller, nevertheless, suggested expanding Romer's original concept of a charter city to a network of charter cities.

\section{Some Conceptual Problems}

The idea behind charter cities may not be easily applied, as it requires the host country or a group of host countries to buy into the concept. Also, given the level of transparency it requires, one may need to check the developing country's Corruption Perceptions as a possible indicator of the level of trust and transparency to expect from its government and people. Fuller and Romer (2012) proposed five initial members of a Transparency Commission that could advise the host in forming a nine-member more permanent team. It was not clear whether the experiment failed because of personalities or broader structural issues. Independent of corruption factors, some developing countries are so politically volatile that it may not be prudent to set up a charter city in them. Also, extremists may not want the introduction of more Western ideas to their lands, so even if a country like Nigeria were open to hosting a charter city, these extremists would try to frustrate the concept.

What happened in Venice and Hong Kong in the past may not work in another country, say Nigeria, which is so culturally-diverse to the extent that unity among the diverse groups has been elusive for decades. Charter cities can also stir up discord if those in the developing nations think that developed countries are using them to prevent them from migrating to the developed world. On the other hand, westerners can be xenophobic, so they may be relieved to not have to live with refugees and immigrants who probably do not look or behave like them. Whether this is true or not is irrelevant. The fact that some people in developing nations have this thought will generate strong opposition voices to the concept of charter cities.

Objectively speaking, Romer's idea may be applied on a case-by-case basis or holistically on a large scale, but it is probably more relevant to ask what should be the appropriate beachhead for this concept to land. This may very well require a blue print taking into consideration the culture of the people and peculiarities of each nation in question. Those refugees who flee war zones may have no choice, and a charter city would certainly be a welcome sanctuary for them instead of a refugee camp. Life is often about timing and luck. A single event or catastrophe can turn the fortunes of any country upside-down and render its citizens destitute. Venezuela was a rich country, but its people are suffering today because of political turmoil caused by harmful domestic and foreign policies (Falola, 2018).

\section{Theory First or Action First}

Romer's idea of charter cities is worth further consideration in spite of the conceptual problems pointed out above. However, the question is whether all potential theoretical and administrative problems should be ironed out before the concept can be seriously considered. A pragmatic way to deal with any problem is to first promote communication and dialogue with the people who may be affected by it. Of course, addressing some of their basic needs would result in immediate gains, but providing opportunities for them to trade and discuss governance issues among themselves should be the next step. Thus, promoting connectivity in refugee camps should be the first step. 
According to a the UNHCR's 2016 findings, addressing to how internet and mobile connectivity can improve refugee well-being and transform humanitarian action, roughly $70 \%$ of mobile network infrastructure in refugee camps are inadequate (with $2 \mathrm{G}$ coverage only) and $20 \%$ of the rural refugee population has no coverage at all. Also, $16 \%$ and $43 \%$ of the urban and rural refugee populations, respectively, have no phone at all (UNHCR, 2016). The barriers to widespread mobile usage are affordability, usability, and availability. Aside from a promoting of infrastructure from $2 \mathrm{G}$ to at least $3 \mathrm{G}$, and it is at least at this level of technology sophistication that refugees can exchange and process information, advance educational and economic opportunities, various action-oriented supports, liaise initiatives with regulators and ISPs, promoting digital literacy and enhancing service delivery have been suggested. UNHCR's Division of Information Systems and Telecommunications (DIST), in collaboration with Accenture Development Partnerships (ADP), launched a Global Connectivity Strategy for Refugees to deal with these inadequacies.

Clearly, without the needed infrastructure to permit experimentation with exchanges and dialogues, refugees will have no choice but to rely on what they are given. Thus, to achieve better connectivity in refugee communities, developing the necessary communication infrastructure is indeed the first step. Considering the vast subsidy that the world considers providing to solve the refugee crisis, improving connectivity AMONG them should be an easy and relatively inexpensive first step. UNHCR estimated a budget of US6 million for the first year.

Subsidised technologies in refugee camps will allow their underprivileged inhabitants to advance. There are private initiatives doing this direction already. Aside from the blockchain experiments noted earlier, a company in Vancouver, Canada, has mobile phone initiatives targeted at refugee camps. These initiatives use an entirely software-based technology and require no special hardware or infrastructure investment (i.e., smartphones) to form networks. The innovative aspect of this initiative is that every mesh node has an Ethereum ID instead of an IP address. The initiatives aim for each node to have a crypto wallet to provide its user with a gateway to financial inclusion. The company plans to use Bluetooth, wi-fi, wi-fi direct, and wi-fi P2P to ensure fast, multi-hop connectivity at the edge of the network with minimum investment in telecommunications infrastructure.

Hempel (2018), citing World Bank, revealed an appalling fact that more than 1 billion people in this world live without any personal identity. This is a direction of development that technology companies with blockchain experience can make a significant contribution. Blockchain technology has been noted for its superiority in a decentralized recording methodology that can help to establish a refugee's identity, a factor extremely crucial no matter where a refugee will eventually settle down. If blockchain transaction mechanisms can be introduced into refugee camps, it will not only facilitate commercial transactions and dialogues conducive for self-governance, but can also help in establishing the self-identity and dignity of refugees as persons that can be useful to build their second lives as part of the world's treasures.

Public-private initiatives of the nature of the particular technology interviewed in this paper are likely to be numerous. Having technology companies with blockchain technologies involved has the advantage of building up accurate and personalized records of individuals over time, using those records across borders as a form of personal identity, creating the trust that is needed in interacting with the rest of the world, without necessarily depending on a government or a bank to vouch for them. In this regard, the authors believe that UNHCR's action to integrate and work with existing UNHCR and partner initiatives, such as the Community Technology Access (CTA) programme, and the digital identification experts in the United Nations Office of Project Services (UNOPS), could be effectively steps moving in the right direction.

\section{CONCLUSION}

According to the $\mathrm{UN}$, the urban population in less developed regions is expected to double in the next four decades from about 2.5 billion to over five billion people. This paper argues that the three prevalent methods of accommodating refugees viz integration, repatriation or resettlement are unsustainable. Indeed, they can feed on a dependent mentality overshadowing the inert strength of the refugees. 
Incorporating and improving technologies and governance structure can offer new choices to reformminded political leaders as well as to migrants in search of better places to live and work.

We have explained the landscape of the current global refugee crisis and suggested prospects for digitizing refugee camps to promote mobile communication and blockchain technology for selfgovernance. Although this may not solve some of the immediate refugee crisis problems, it has the potential of solving a deep-rooted refugee problem in some way created by the political economy of the developing world. While concrete policies still have to be hammered out, our paper suggests a combination of new technologies and governance structure that can facilitate new directions for resolving a problem that has arguably gotten out of hand. The UN, NGOs, host countries, and social entrepreneurs can work together to establish the infrastructure needed to facilitate the implementation of experimental measures in this direction, which should benefit refugees in the long run.

Refugees are an important source of human capital who should be given opportunities to develop their potential rather than to languish in refugee camps. Developed nations, together with the UN, need to work together to identify locations where charter cities can be built - perhaps with the assistance of the refugees themselves - and, in the process, create better lives for these displaced people. The selection of a combination of technologies and governance structure is a strategic innovation itself that if applied for the appropriate beachhead could set new direction for effective new solutions for refugee problems .

The refugee crisis will not abate unless wars and oppression cease, and people are content with remaining in their own countries, but it cannot be solved solely through traditional aid. Offering refugees a chance to better their lives and work in safe, well-run cities that provide opportunities for them to grow and offer more support to their families can help alleviate the refugee crisis. Paul Romer, in his original formulation of the idea, has foreseen that our "limited capacity to discover and implement new rules" is the principal constraint to raising living standards. This paper points out that an integration of blockchain together with improvement in connectivity, emphasizing peer-to-peer communication, can be a concrete step to move in this direction.

\section{ENDNOTES}

1. A refugee camp is a place built by governments or non-governmental organisations (NGOs) such as the Red Cross to receive refugees, internally displaced people (IDPs), and sometimes other migrants. It is usually designed to offer acute and temporary accommodation and services. However, some people stay in these camps for many years, receiving emergency food, education, and medical aid until it is safe enough to return to their countries of origin. In these camps, refugees are at risk of disease, child soldier and terrorist recruitment, and physical and sexual violence. There are about 700 refugee camp locations worldwide. It is noteworthy that not all refugees who are supported by the UNHCR live in refugee camps. A substantial number live in urban settings such as the 63,500 Iraqi refugees in Damascus, Syria (Dehghanpisheh, 2013) and $\sim 30,000$ Sudanese refugees in Cairo, Egypt (Mahmoud, n.d.).

2. The UN 1951 Refugee Convention, issued after World War II, defined a refugee as one who, "owing to well-founded fear of being persecuted for reasons of race, religion, nationality, membership of a particular social group or political opinion, is outside the country of his nationality and is unable or, owing to such fear, is unwilling to avail himself of the protection of that country; or who, not having a nationality and being outside the country of his former habitual residence as a result of such events, is unable or, owing to such fear, is unwilling to return to it" (OHCHR, 2012). This definition has been revised and expanded and, as of 2011, the United Nations High Commissioner for Refugees (UNHCR) adding to the 1951 definition, recognizes as refugees, people "who are outside their country of nationality or habitual residence and unable to return there owing to serious and indiscriminate threats to life, physical integrity or freedom resulting from generalized violence or events seriously disturbing public order." The office of the UNHCR, headquartered in Geneva, Switzerland, has the primary tasks of safeguarding the rights and wellbeing of refugees worldwide to ensure that everyone can exercise the right to seek asylum (the right to international protection), find safe refuge in other states or territories, and offering "durable solutions" to refugees and refugee-hosting countries.

3. Refugee crisis can refer to movements of large groups of displaced people who could be either internally displaced people, refugees, or other migrants. It can also refer to incidents in the refugees' countries of 
origin or departure or to large problems whilst on the move or even after arrival in relatively safe countries that involve large groups of displaced people. In 2006, there were 8.4 million UNHCR registered refugees worldwide. By the end of 2015, this figure increased to 16.1 million. If the 5.2 million Palestinian refugees who are under the United Nations Relief Work Agency's (UNRWA) mandate were added, the figure would be 21.3 million. Overall forced displacement worldwide reached 65.3 million displaced people by the end of 2015, while it was 59.5 million in 2014. One in every 113 people globally is an asylum seeker or refugee (BBC News, 2016). According to UNHCR (2015), Syrian refugees were the largest group in 2015 comprising 4.9 million people. Afghan refugees were 2.7 million and Somalis were the third largest group with one million. The countries hosting the largest number of refugees, according to the UNHCR, were Turkey (2.5 million), Pakistan (1.6 million), Lebanon (1.1 million), and Iran (one million). The countries that had the largest numbers of IDPs were Colombia (6.9 million), Syria (6.6 million), and Iraq (4.4 million). Children were 51\% of refugees in 2015 and most were separated from their parents or travelling alone. In $2015,86 \%$ of the refugees under the UNHCR's mandate were in lowand middle-income countries that themselves were in precarious situations (Edwards, 2016).

4. Local integration aims at providing refugees with the permanent right to stay in their countries of asylum including, in some situations, as naturalised citizens. In 2014, Tanzania granted citizenship to 162,000 refugees from Burundi and in 1982 to 32,000 Rwandan refugees (Markus, 2014). Mexico naturalised 6,200 Guatemalan refugees in 2001 (Goldberg, 2001).

5. Repatriation is the voluntary return of refugees to their countries of origin in safety and dignity based on their free will and informed decision. In the last couple of years, some refugees were able to return to their home countries: e.g. 120,000 Congolese refugees returned from the Republic of Congo to the Democratic Republic of Congo (DRC); 30,000 Angolans returned home from the DRC (Schmitt, 2014) and Botswana, Ivorian refugees returned from Liberia, Afghans from Pakistan, and Iraqis from Syria. In 2013, the governments of Kenya and Somalia also signed a tripartite agreement facilitating the repatriation of refugees from Kenya to Somalia (Olick, 2014).

6. Resettlement involves the assisted transfer of refugees from the country in which they seek asylum to safer third countries that agree to admit them as refugees. This can be for permanent settlement or for a certain number of years. It is the third durable solution and usually the least preferred. Hence it is only considered if the two other solutions are impossible.

7. https://study.com/academy/lesson/seven-mile-bridge-construction-history-facts.html. See also interesting historical account in (Klingener, 2015). Of course, prior to the founding of America, residence in a particular locality is a matter of governance (Albelda, 2014) .

8. The Cuban government accuses Miami-based exiles of organizing over 700 armed incursions against Cuba over the past 40 years such as machine-gun attacks on the Guitart Cayo Coco Hotel by Alpha 66 in 1994 and 1995.

The Cuban government has long contended that some South Florida Spanish-language journalists are paid by the U.S. government. On September 8, 2006, it was revealed that at least ten South Florida journalists, veteran reporters and a freelancer including some associated with the El Nuevo Herald, received payments totaling thousands of dollars over several years from the U.S. government for programs on Radio Martí and TV Martí, broadcasts aimed at undermining the Cuban state.

In November 2006, U.S. Congressional auditors accused the development agency USAID of failing properly to administer its program to promote democracy in Cuba. They said that USAID had channeled tens of millions of dollars through exile groups in Miami, which were sometimes wasteful or kept questionable accounts. The report said the organizations had sent items such as chocolate and cashmere jerseys to Cuba. Their report concluded that $30 \%$ of the exile groups who received USAID grants showed questionable expenditures.

9. Major NGOs

- Bangladesh Rural Advancement Committee (BRAC): Founded in 1972 to aid the return of thousands of refugees after Bangladesh's war of independence, BRAC now has approximately 125,000 employees and reaches 7,000 villagers and 2,000 slums with its services and micro-credit system. Its mission is to improve the health of poor people, manage their medical problems, reduce poverty, provide technical assistance, etc. (Miratel, 2013).

- Danish Refugee Council (DRC): Founded in 1956, it serves as a humanitarian aid organization for primarily European refugees. DRC also provides services to the neediest and poorest people around the world. 
- Medecins Sans Frontieres (MSF): Founded in 1971, it bases its services on the principles of humanitarian assistance by providing medical care to refugees during crises including the setting up of hospitals, clinics, nutrition centers, and surgery stations. It is a medical humanitarian organization that operates worldwide.

- Mercy Corps: Founded in 1979 and known back then as the Save the Refugees Fund, this NGO focuses on political upheavals and economic collapses, places in transition, disasters, and conflicts by providing emergency relief in such situations.

- International Rescue Committee: Established in 1942 specifically for refugees of World War II, it has since provided emergency assistance to refugees in many countries. It aims to restore people's dignity, safety, and hope. Its activities include medical assistance, community rebuilding, protection of women and children, and rebuilding homes for refugees (Miratel, 2013).

\section{ACKNOWLEDGEMENTS}

The authors wish to thank the suggestions of Vera Balazelkoska of ulula in an MBA student project at NYIT. John Lyotier, Dana Harvey, Brianna MacNeil provided valuable information on the RightMesh refugee initiatives. Editorial help from the journal is greatly appreciated.

\section{REFERENCES}

Anderson, S. (2018). The city born in a day". New York Magazine-Intelligencer. Retrieved from http://nymag.com/intelligencer/2018/08/how-oklahoma-city-was-born-in-aday.html?gtm=top\&gtm=top.

Albelda, J. (2014). Black Miami- the history you never learned. The World or Bust. Retrieved from http://www.theworldorbust.com/black-miami-the-history-you-never-learned/.

Anzilotti, E. (2017). Refugee camps are turning into permanent cities- can they be smart cities? Fast Company. Retrieved from https://www.fastcompany.com/40441141/refugee-camps-are-turninginto-permanent-cities-can-they-be-smart-cities.

BBC News (2016, June 20). Refugees at highest ever level, reaching 65m, says UN. BBC News. Retrieved from http://www.bbc.com/news/world-36573082

Castle-Miller, M. (2012). The governance market: A new vision for Paul Romer's charter cities concept. Retrieved from SSRN: https://ssrn.com/abstract $=2458669$ or http://dx.doi.org/10.2139/ssrn.2458669.

Castle-Miller, M. R. (2014). The Ciudades Modelo project: Testing the legality of Paul Romer's Charter Cities concept by analyzing the constitutionalityof the Honduran 'Zones for Employement and Economic Development. Willamette Journal of International Law and Dispute Resolution, 22, 271-312.

Clapp, J. (1986). Shylock's ghetto: the place of the play. Place,3(2). Retrieved from https://nyitonline.nyit.edu/bbcswebdav/pid-2366227-dt-content-rid6182346_2/courses/ECON_745-VA1-2018SP-VR/Shylock\%20Ghetto.pdf

CONNECTING REFUGEES How Internet and Mobile Connectivity can Improve Refugee Well-Being and Transform Humanitarian Action. (2016).

Dehghanpisheh, B. (2013). Iraqi refugees in Syria feel new strains of war. The Washington Post. Retrieved from https://www.washingtonpost.com/world/middle_east/iraqi-refugees-in-syria-feelnew-strains-of-war/2013/04/09/4f5cd784-9ee8-11e2-a941a19bce7af755_story.html?noredirect $=$ on\&utm_term $=$. cf37e $7323 \mathrm{~d} 62$

Edwards, A. (2016). Global forced displacement hits record high. United Nations High Commissioner for Refugees. Retrieved from http://www.unhcr.org/news/latest/2016/6/5763b65a4/global-forceddisplacement-hits-record-high.html 
Falola, A. (2018). From riches to rags- Venezuelans become Latin America's new underclass.

Washington Post. Retrieved from

https:/www.washingtonpost.com/news/world/wp/2018/07/27/feature/as-venezuela-crumbles-its-

fleeing-citizens-are-becoming-latin-americas-new-

underclass/?noredirect $=$ on\&utm_term $=.02 \mathrm{ebb} 47 \mathrm{~d} 13 \mathrm{f} 4$

Fuller, B., Romer, P. (2012). Success and the city: how charter cities could transform the developing world. MacDonald-Laurier Institute. Retrieved from

https://www.macdonaldlaurier.ca/files/pdf/How-charter-cities-could-transform-the-developingworld-April-2012.pdf

Global trends: forced displacement 2015 (2015). United Nations High Commissioner for Refugees.

Retrieved from http://www.unhcr.org/576408cd7

Goldberg, D. (2001). From refugee to citizen: a Guatemalan in Mexico: a Central American success story. United Nations High Commissioner for Refugees. Retrieved from http://www.unhcr.org/3c064aab4.html.

Hempel, J. (2018). How refugees are helping create blockchain's brand new world. Wired Newsletter. Retrieved from https://www.wired.com/story/refugees-but-on-the-blockchain/

Juskalian, R. (2018). Inside the Jordan refugee camp that runs on blockchain. MIT Technology Review. Retrieved from https://www.technologyreview.com/s/610806/inside-the-jordan-refugee-campthat-runs-on-blockchain/

Klingener, N. (2015). When Key West was Cuban. WLRN Public Radio \& Television. Retrieved from http://www.wlrn.org/post/when-key-west-was-cuban

Lai, L.W.C., Lu, W.W.S., \& Lorne, F.T. (2014a). A catallactic framework of government land reclamation: The case of Hong Kong and Shenzhen. Habitat International, 44, 62-71.

Lai, L.W.C., Chua, M.H., \& Lorne, F.T. (2014b). The Coase theorem and squatting on crown land and water: a Hong Kong comparative study of the differences between the state allocation of property rights for two kinds of squatters. Habitat International, 44, 247-257.

Lai, L.W.C., Chau, K.W., \& Lorne, F.T. (2019). Forgetting by Not Doing: an Institutional Memory Inquiry Forward Planning for Land Production by Reclamation. Land Use Policy, 82, 796-806.

Lorne, F., Daram, S., Frantz, R., Kumar, N., Mohammed, A., \& Muley, A. (2018). Blockchain Economics and Marketing. Journal of Computer and Communications, 6, 107-117. doi: $10.4236 /$ jcc.2018.612011

Mahmoud, H.W. (n.d.). Shattered dreams of Sudanese refugees in Cairo". Forced Migration Review (FMR). Retrieved from http://www.fmreview.org/sites/fmr/files/FMRdownloads/en/FMRpdfs/FMR27/50.pdf

Markus, F. (2014). Tanzania grants citizenship to 162,000 Burundian refugees in historic decision. United Nations High Commissioner for Refugees. Retrieved from http://www.unhcr.org/5441246f6.html

Miratel Inc. Solutions (2013). 10 Top NGO from the Global Journal 100 Best List 2013. Retrieved from http://www.miratelinc.com/blog/10-top-ngo-from-the-global-journal-100-best-list-2013/

Olick, F. (2014). Nairobi to open mission in Mogadishu. Standard Digital. Retrieved from https://www.standardmedia.co.ke/mobile/?articleID=2000105058\&story_title=nairobi-to-openmission-in-mogadishu

Office of the High Commissioner for Human Rights (2012). Convention relating to the status of refugees. Office of the High Commissioner for Human Rights. Retrieved from https://web.archive.org/web/20120607013438/http://www2.ohchr.org/english/law/refugees.html

Perper, R. (2018). Sierra Leone just became the first country in the world to use blockchain during an election. Business Insider. Retrieved from https://www.businessinsider.com/sierra-leoneblockchain-elections-2018-3?IR=T

Romer, Paul. (2010). Technologies, Rules, and Progress: The Case for Charter Cities. Center for Global Development. Retrieved from https://www.files.ethz.ch/isn/113646/1423916_file_TechnologyRulesProgress_FINAL.pdf 
Roth, Cecil. (1934). The Origin of Ghetto, a final word. Romanian, 67-76. Retrieved from https://www.persee.fr/doc/roma_0035-8029_1934_num_60_237_4174

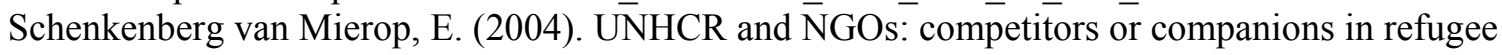
protection? Migration Policy Institute. Retrieved from https://www.migrationpolicy.org/article/unhcr-and-ngos-competitors-or-companions-refugeeprotection

Schiller, B. (2014). Using mobile phone payments to get people with no credit history some credit. Fast Company. Retrieved from https://www.fastcompany.com/3035336/using-mobile-phonepayments-to-get-people-with-no-credit-history-some-credit

Schmitt, C. (2014, August 5). UNHCR completes challenging repatriation of almost 120,000 Congolese refugees. United Nations High Commissioner for Refugees. Retrieved from http://www.unhcr.org/53ff4c3c6.html

Torobin, J. (2018). How 'charter cities' could lift the global economy. The Globe and Mail. Retrieved from https://www.theglobeandmail.com/report-on-business/economy/economy-lab/how-chartercities-could-lift-the-global-economy/article4102675/

UNHCR (2011). UNHCR resettlement handbook. United Nations High Commissioner for Refugees. Retrieved from_http://www.unhcr.org/46f7c0ee2.pdf

Wikipedia (n.d.). Charter city.

Wikipedia (n.d.). Cuban Exile.

Wikipedia (n.d.). Saipan.

Wikipedia (n.d.). Za'atari refugee camp.

Xu, Y., \& Maitland, C. (2015). A social informatics analysis of refugee mobile phone use: a case study of Za'atari Syrian refugee camp. Social Science Research Network.

Xu, Y., Maitland, C., \& Tomaszewski, B. (2015). Promoting participatory community building in refugee camps with mapping technology. Retrieved from https://cmaitland.ist.psu.edu/wpcontent/uploads/sites/9/2015/01/XuMaitlandTomaszewski2015ParticipatoryMapping.pdf 